\title{
A LA TERCERA SE GANA: THE VALIDATION OF BENZINGIA (ORCHIDACEAE: ZYGOPETALINAE)
}

\author{
Gustavo A. Romero-GonzÁlez ${ }^{1} \&$ Calaway H. Dodson ${ }^{2}$ \\ ${ }^{1}$ Keeper, Orchid Herbarium of Oakes Ames, Harvard University Herbaria, 22 Divinity Avenue, Cambridge, \\ Massachusetts 02138, U.S.A.; romero@oeb.harvard.edu \\ ${ }^{2}$ Curator Emeritus, Missouri Botanical Garden, 4344 Shaw Boulevard, St. Louis, Missouri 63110, U.S.A.; \\ calaway.dodson@gmail.com
}

\begin{abstract}
Aвstract. When Benzingia was first proposed in 1989, the protologue included two species (Benzingia hirtzii sp. nov. and B. estradae comb. nov.), which required two separate Latin descriptions or diagnoses (generic and specific) for Benzingia and B. hirtzii. The author, however, provided only a descriptio generico-specifica. Therefore, the generic name, the new species, and the proposed combination were not validly published. An attempt to validate the genus and the two species was made by Dodson and Romero in 1995, but it also failed because it did not include separate Latin descriptions for the genus and the proposed type species. Seven species names referred to Benzingia in the meantime are also invalid. All the ten relevant names are here validated (the generic name, the new species, and eight new combinations).

RESUMEN. Cuando se propuso Benzingia por primera vez en 1989, el protólogo incluía dos especies (Benzingia hirtzii sp. nov. у B. estradae comb. nov.), lo que requería descripciones o diagnosis en latín separadas para el género y para la especie nueva. Sin embargo, el autor sólo publicó una descriptio generico-specifica. Por consiguiente, Benzingia, la especie nueva y la nueva combinación no fueron publicadas válidamente. Se trató de validar el género en 1995, pero el esfuerzo falló porque no se incluyeron las descripciones separadas en latín del género y de la especie tipo. Mientras tanto, los nombres de las siete especies adicionales que hasta el momento se han referido a Benzingia también son inválidos. Aquí se validan los diez nombres relevantes (el nombre genérico, la especie nueva y ocho nuevas combinaciones).
\end{abstract}

KeY words: Benzingia, Orchidaceae, validation, Zygopetalinae

Introduction. The genus Benzingia Dodson was first proposed in 1989. A descriptio generico-specifica was provided for the generic name and for a new species, B. hirtzii Dodson. In the protologue, however, Dodson (1989) also proposed a new combination, transferred from Chondrorhyncha Lindl. According to article 42.1 of the International Code of Botanical Nomenclature (McNeill et al., 2006), Benzingia, the new species, and the proposed combination were not validly published (see Art. 42.1, Ex. 1), because two separate Latin descriptions or diagnoses were required for the generic name and the new species.

Dodson and Romero (1995) attempted to validate the genus but failed to provide the required separate Latin descriptions for the genus and the type species: the names included therein were again not validly published. In the meantime, seven additional new combinations have been proposed in Benzingia
(Dressler in Whitten et al., 2005; Harding, 2008: 32). Since the generic name had not been validly published, however, these names are considered invalid.

Benzingia and $B$. hirtzii are validly described here, for which we provide separate Latin diagnoses, and eight relevant names at the rank of species are validated. In personal communications, both R. L. Dressler and P. A. Harding consented to have their new combinations republished here.

Benzingia Dodson, gen. nov.

Synonyms: Ackermania Dodson \& R.Escobar, Orquideología 18: 202. 1993, non Ackermannia Pat. (1902).

Benzingia Dodson, Icon. Pl. Trop. Ser. 2, 5: t. 406. 1989, nom. invalid.

Benzingia Dodson, Lindleyana 10: 74. 1995, nom. invalid. 
TYPE: Benzingia hirtzii Dodson

Habitus Steniae Lindl. similis sed labello spathulato non profunde saccato, et habitus Chondrorhynchae Lindl. similis sed sepalis patentibus nec retrorsis neque falcatis distinguitur.

Benzingia caudata (Ackerman) Dressler, comb. nov.

Basionym: Chondrorhyncha caudata Ackerman, Selbyana 5: 299. 1981.

Synonym: Benzingia caudata Dressler, Lankesteriana 5: 93. 2005, nom. invalid.

Benzingia cornuta (Garay) Dressler, comb. nov.

Basionym: Chondrorhyncha cornuta Garay Orquideologia 5: 20. 1970.

Synonym: Benzingia cornuta Dressler, Lankesteriana 5: 93. 2005, nom. invalid.

Benzingia estradae (Dodson) Dodson, comb. nov.

Basionym: Chondrorhyncha estradae Dodson, Icon. Pl. Trop. t. 22 (as "Chondroryncha"). 1980. Synonym: Benzingia estradae Dodson, Lindleyana 10: 74. 1995, nom. invalid.

Benzingia hajekii (D.E.Benn. \& Christenson) Dressler, comb. nov.

Basionym: Ackermania hajekii D.E.Benn. \& Christenson, Icon. Orchid. Peruviarum t. 602. 2001.

Synonym: Benzingia hajekii Dressler, Lankesteriana 5: 93. 2005, nom. invalid.

Benzingia hirtzii Dodson, sp. nov.

TYPE: EcuAdor. Imbabura: Santa Rosa de Chaco, 8 $\mathrm{km}$ East North of Lita on road Ibarra to Lita, $1150 \mathrm{~m}$, 19 January 1987, C. H. Dodson, A. Hirtz, D. Benzing \& C. A. Luer 16893 (holotype, MO; isotypes, QCNE, $\mathrm{K}, \mathrm{SEL})$.

Synonym: Benzingia hirtzii Dodson, Icon. Pl. Trop. Ser. 2, 5: t. 406. 1989, nom. invalid.

Benzingia hirtzii Dodson, Lindleyana 10: 74. 1995, nom. invalid.

Species haec Benzingiae estradae (Dodson) Dodson similis, sed inflorescentia erecta, labello basi leviter concavo apice rotundo et ovario geniculato distinguitur.

Epiphyte. Plant to $15 \mathrm{~cm}$ tall. Rhizome short, stems erect, very short, without pseudobulbs, surrounded by imbricating, distichous leaf-bearing sheaths. Leaves elliptic-oblong, acuminate at the apex, narrowing to the base and the articulated junction with the sheath, membranaceous, to $12 \times 1.6 \mathrm{~cm}$. Inflorescence 1 -flowered, erect, usually one inflorescence produced from each leaf sheath. Floral bracts triangular, $3 \mathrm{~mm}$ long. Ovary geniculate so that flower is nonresupinate, to $2 \mathrm{~cm}$ long, terete. Flower yellow, the sepals and petals spotted with red-brown, the lip yellow with an orange callus, abundantly spotted with red-brown. Sepals spreading, free; dorsal sepal oblong-ovate, 1.7 $\mathrm{x} 0.5 \mathrm{~cm}$; lateral sepals obliquely oblong-ovate, $1.8 \mathrm{x}$ $0.5 \mathrm{~cm}$. Petals oblong-ovate, spreading, obtuse, $1.7 \mathrm{x}$ $0.5 \mathrm{~cm}$. Lip shallowly concave, scoop-shaped, rotund, not surrounding the column, $2.2 \times 2.2 \mathrm{~cm}$, united to the column foot at the base, with a flat callus down the midline. Column arcuate, subterete, slightly winged on each side below the stigma, $1.5 \mathrm{~cm}$ long, produced into a terete foot $0.8 \mathrm{~cm}$ long. Pollinia in 2 unequal pairs attached to a rectangular stipe, the latter attached to a cordiform viscidium.

Benzingia jarae (D.E.Benn. \& Christenson) Dressler, comb. nov.

Basionym: Ackermania jarae D.E.Benn. \& Christenson, Brittonia 47: 182. 1995.

Synonym: Benzingia jarae Dressler, Lankesteriana 5: 93. 2005, nom. invalid.

Benzingia palorae (Dodson \& Hirtz) Dressler, comb. nov.

Basionym: Stenia palorae Dodson \& Hirtz, Icon. Pl. Trop. ser. 2, 6: t. 583. 1989.

Synonym: Benzingia palorae Dressler, Lankesteriana 5: 93. 2005, nom. invalid.

Benzingia reichenbachiana (Schltr.) Dressler, comb. nov.

Basionym: Chondrorhyncha reichenbachiana Schltr., Repert. Spec. Nov. Regni Veg. 17: 15. 1921.

Synonym: Benzingia reichenbachiana Dressler, Lankesteriana 5: 93. 2005, nom. invalid.

Benzingia thienii (Dodson) P.A.Harding, comb. nov.

Basionym: Cochleanthes thienii Dodson Icon. Pl. Trop. t. 26. 1980.

Synonyms: Chondrorhyncha thienii (Dodson) 
Dodson Selbyana 7: 354. 1984.

Benzingia thienii P.A.Harding, Huntleyas 32. 2008, nom. invalid.
Acknowledgments. We are grateful to P. Ormerod for pointing out the errors in the 1995 publication, to K. Gandhi for reviewing the manuscript, and to R. L. Dressler and P. A. Harding for their cooperation.

\section{LitERATURE CITED}

Dodson, C. H. 1989. Benzingia hirtzii. Icon. Pl. Trop. Ser 2, 5: t. 406.

Dodson, C. H. \& G. A. Romero 1995. Revalidation of the genus Benzingia (Zygopetalinae: Orchidaceae). Lindleyana 10: 74.

Harding, P. A. 2008. Huntleyas and Related Orchids. Timber Press, Portland, Oregon.

McNeill, J. et al. 2006. International Code of Botanical Nomenclature (Vienna Code). Regnum Vegetabile 146. A.R.G. Gantner Verlag KG, Ruggell, Liechtenstein.

Whitten, W. M., N. Williams, R. L. Dressler, G. Gerlach, \& F. Pupulin. 2005. Generic relationships of Zygopetalinae (Orchidaceae: Cymbidieae): combined molecular evidence. Lankesteriana 5: 87—107. 